УДК 316.245:334.52:342.6:347:354:356.2:454.5:642:647:74.2

\section{Вукчевич Н. \\ Анализ взаимосвязи миграции и религии в социологических исследованиях на материалах республики Сербия}

Университет Белграда

Студенческая площадь, 1, Белград, 11000, Сербия;

Белгородский государственный технологический университет

им. В. Г. Шухова

ул. Костюкова, 46, Белгород, 308012, Россия

vukcevic.nemanja75@gmail.com

\begin{abstract}
Аннотация. В ходе рассмотрения двух древнейших феноменов - миграции и религии, делается попытка определить характер их взаимосвязи, которая в целом может играть значительную роль в современных общественных процессах. В фокусе работы находятся актуальные перемещения населения, ставшие последствием Европейского миграционного кризиса 2015 года. Во введении показано, что помимо двух рассматриваемых феноменов глубоко уходит корнями в прошлое и их взаимосвязь. Внимание обращено на некоторые международные и неправительственные организации, которые вовлечены в являющийся объектом нашего исследования кризис. Исследование на материалах Республики Сербия, включает анализ результатов авторского опроса в центрах постоянного пребывания мигрантов и беженцев, контент-анализ релевантных медиа-сообщений, а также вторичный анализ социологических данных Центра свободных выборов и демократии, Центра прикладных общественных исследований и анализ данных анкетирования граждан, проживающих в центральной части страны. Предположение о наличие взаимосвязи исследуемых переменных миграции с религиозной принадлежностью респондентов проверяется с помощью статистических методов. Несмотря на то, что анализ взаимосвязи религии и миграции в статье проводится на локальном примере, изучение мнения как представителей принимающего сообщества, так и самих мигрантов позволяет получить новое более точное представление о глобальной картине общественных изменений, которые происходят сегодня. Полученные выводы могут быть полезны для установления равновесия социальной системы в неблагоприятных условиях миграционного кризиса.
\end{abstract}

Ключевые слова: религия; миграция; беженцы; взаимосвязь; результаты исследования

Информация для цитирования: Вукчевич Н. Анализ взаимосвязи миграции и религии в социологических исследованиях на материалах республики Сербия // Научный результат. Социология и управление. 2020. Т. 6, № 3. С. 91-107. DOI: $10.18413 / 2408-9338-2020-6-3-0-6$. 


\title{
Analysis of the relationship of migration and religion Nemanja Vukcevic (iD $\quad$ in sociological research on the materials of the republic of Serbia
}

\author{
University of Belgrade \\ 1, Studentski trg., Belgrade, 11000, Serbia; \\ Shukhov Belgorod State Technological University \\ 46 Kostyukov St., Belgorod, 308012, Russia \\ vukcevic.nemanja75@gmail.com
}

\begin{abstract}
Considering the two oldest phenomena - migration and religion, the author attempts to determine the nature of their relationship, which in general can play a significant role in modern social processes. The focus of this work is on the current population movements caused by the European migration crisis in 2015. The introduction shows that besides the two considered phenomena, their relationship is deeply rooted in the past. Attention is drawn to some international and non-governmental organizations that are involved in the crisis that is the subject of our research. The research based on the materials of the Republic of Serbia includes an analysis of the results of the author's survey in the centers of permanent residence of migrants and refugees, content analysis of relevant media messages, as well as a secondary analysis of sociological data of the Center for Free Elections and Democracy, the Center for Applied Public Research and analysis of survey data from citizens living in the central part of the country. The assumption that there is a relationship between the studied migration variables and the religious affiliation of the respondents is tested using statistical methods. Despite the fact that the analysis of the relationship between religion and migration in the article is carried out on a local example, the study of the opinions of both representatives of the receiving community and the migrants themselves allows to get a new, more accurate idea of the global picture of social changes that are taking place today. The findings can be useful for establishing the balance of the social system in the unfavorable conditions of the migration crisis.
\end{abstract}

Keywords: religion; migration; refugees; interconnections; research results

Information for citation: Vukcevic, N. (2020), "Analysis of the relationship of migration and religion in sociological research on the materials of the republic of Serbia", Research Result. Sociology and Management, 6 (3), 91-107, DOI: 10.18413/2408-93382020-6-3-0-6.

Введение (Introduction). До сих пор открытым остается вопрос о степени научной разработанности проблемы взаимосвязи миграции и религии. В то время как отдельные авторы говорят, что «взаимосвязь между иммиграцией, гражданством, интеграцией и включением в принимающее общество долгое время занимала центральное место в области научного интереса исследователей» (Cesari, 2017: 9), имеет место и прямо противоположная точка зрения. Однако, несмотря на то, какое из данных двух утверждения является верным, мы полагаем, что установлены отдельные факты, которые, возможно, лучше интерпретировать как косвенные выводы. Например, в связи с воспитанием, «когда дело касается второго и последующих поколений, религиозный вопрос имеет первостепенное значение: формирование идентичности детей иммигрантов, безусловно, является важнейшей темой и роль, которую религиозные верования играют в его формировании, общепризнана» (Cesari, 2017: 10). Или, в области экономики, 
где «можно сказать, что переплетение миграции и религии приводит к рассмотрению в тесной взаимосвязи с данными феноменами других систем, таких как рынок труда (например, дискриминируются ли мусульмане по сравнению с людьми с другой религиозной принадлежностью?), образование (обуславливает ли увеличение числа студентов, не являющихся христианами, просьбы о секуляризации и других изменениях?), школьные расписания и т.д.» (Cesari, 2017: 10). Феномены миграции и религии пересекаются даже в местах лишения свободы. «Так, тюрьмы являются одной из проблемных точек пересечения религий и миграции, хотя эта конкретная область не исследовалась социологами так интенсивно, как следовало бы» (Beckfor, 2019: 22). Отметим, что, например, не имеющий обязательной юридической силы документ Совета Европы под названием «Европейские тюремные правила» включает три основных касающиеся данного вопроса положения под общим заголовком «Свобода мысли, совести и религии» (Beckfor, 2019: 24).

Методология и методы (Methodology and methods). Конечно, хотя отмеченная взаимосвязь имеет косвенный характер, как мы и сказали, ее также совершенно точно можно отметить в случае миграции и религии. Это еще один аргумент в пользу того, что мультидисциплинарный подход к изучению общества в этом случае не только желателен, но и необходим. В остальном мы придерживаемся мнения о том, что отказ от междисциплинарности в области общественных наук и, в связи с этим, узкая специализация отдельных ее отраслей, на основе утверждения о том, что общество само по себе слишком сложное, в частности, когда речь идет о религии - парадоксален (Вукчевич, 2019c). Так, один из порожденных подобным подходом парадоксов, названный Эзрой Аитар и Питером Бодором «парадоксом хиджаба», был принят нами во внимание в ходе нашего исследования проблемы взаимосвязи миграции и религии. «Предположительно, первоначальная функция хиджаба заключалось в том, чтобы избежать нежелательного внимания со стороны незнакомцев, особенно мужчин, однако в немусульманской стране, таких как Венгрия, ношение хиджаба может привести к противоположному эффекту» (Cesari, 2017: 11). Могут иметь место и такие недоразумения, когда «люди на самом деле точно не являются мусульманами: арабские христиане-мигранты и выходцы из Южной Азии, исповедующие сикхизм, индуизм, джайнизм или христианство, иногда воспринимаются как мусульмане и, таким образом, также становятся мишенью» (Cesari, 2017: 11).

В арсенале естественных наук также имеется множество парадоксов, которые и сегодня остаются неразрешенными и необъяснимыми, поэтому мы вынуждены их просто принимать, что мы не можем себе позволить в случае общественных науках. Мы не может себе позволить их принимать как данность, так как в отличие от физиков, объектом изучения которых являются некие явления - при этом исследователь находиться вне этого явления, в фокусе внимания социологов находятся отношения, и одна, и другая стороны которых представлена людьми. При этом в таких отношениях должен присутствовать цивилизационный поток, особенно коммуникации, затем - понимание, а после - и решение парадокса. В ином случае, по нашему мнению, нет оснований говорить о цивилизации, по крайней мере, об уникальной человеческой цивилизации. Если мы смиримся с подобным положением вещей в обществе - в замкнутом в себе обществе, где отношения сплоченности присутствуют только собственных групп, то мы должны быть готовы ни к чему другому, кроме как непопулярному «столкновению цивилизаций», как весьма прагматично и реалистично постулировал Самюэль Хантингтон (Huntington, 1996). Таким образом, при исключении гуманистического подхода к разрешению общественной коллизии, парадоксов и рисков, нам остается только подход, основанный на принципе безопасности (Бедин, Гридчин, 1992; Гридчин, 2008). Сле- 
дует подчеркнуть, что в рамках нашей работы мы полностью оставили за пределами исследования принцип безопасности и постарались построить ход наших рассуждений исключительно в гуманистической перспективе.

Как один из аспектов данной гуманистической перспективы «гостеприимство с древних времен было фундаментальной и по сути религиозной мерой нравственности. Гостеприимства уже давно означает нечто большее, чем просто предоставление ресурсов; в большей степени это означает признание человечности другого, что обычно отражает лежащую в его основе божественное присутствие в теологическом понимании. В настоящее время обычным явлением в «анализе заинтересованных сторон» гуманитарных инициатив является рассмотрение местных религиозных лидеров в качестве контрагентов, через которых могут быть мобилизованы определенные группы избирателей или определенные «уязвимые группы» (Cesari, 2017: 11).

Всем так называемым Авраамическим религиям присуще гостеприимство и позитивное отношение к иностранцам, что нашло отражение в их важнейших священных книгах, однако подобный подход имеет место в и индуизме, и даже в древнегреческой религии. Поэтому, можно говорить о том, что религия могла бы и должна была бы способствовать общественной сплоченности всегда, когда дело касается мигрантов. «Жители Медины, которые поддерживали переселенцев из Мекки в 622 году н.э., стали известны как Помощники или Ансары и их восхваляли в Коране (сура 8:74): «А те, которые уверовали, переселились в Медину и сражались на пути Аллаха, и те, которые дали им приют и поддержали их, Истину Аллаха и Его веру - они и есть искренние верующие. Аллах Всевышний их прощает, и для них будет большой удел в ближайшей жизни и в будущей!». В свою очередь, сура 60:8 «побуждает мусульман проявлять доброту и практиковать справедливые отношения с праведниками» (Ager, Ager, 2016: 298-
299). Речь тут идет о суре «Аллах не запрещает вам быть добрыми и справедливыми с теми, которые не сражались с вами из-за религии и не изгоняли вас из ваших жилищ. Воистину, Аллах любит беспристрастных» (Священный Коран, 2007). Как отмечают в своей главе Алайстер Эйджер и Джой Эйджер, «мантра atithi-devo bhava, или «почитай гостя как Бога», в ведийском тексте на санскрите Тайттирия-упанишада, предлагает увидеть божественность в госте, которого приветствуют. Для христиан библейские стихи, такие как 2 стих 13 главы Послания к Евреям: «Всегда помните о гостеприимстве, ибо поступая так, некоторые оказали гостеприимство ангелам, сами того не ведая», и 35 стих 25 главы Евангелия от Матфея, где Иисус говорит о том, что он может явиться в образе незнакомца: «Я был странником, и вы приютили Меня», часто цитируются в рекламных материалах церковных иммиграционных организаций и организаций беженцев, поощряющих как прямую поддержку, так и продвижение терпимости» (Saunders, Fiddian-Qasmiyeh, Snyder, 2016: 30). В «Одиссее Гомера» эти таинственные отношения выражаются в следующих выражениях: Грубость по отношению к чужеземцу - неприличие... Все скитальцы и нищие произошли от Зевса. То, что мы можем дать, невелико, но вознаграждение велико (Saunders, Fiddian-Qasmiyeh, Snyder, 2016: 45).

Сегодня, без большой полемики, которая очевидно могла бы тут возникнуть, мы можем отметить, что в секулярном мире (по крайней мере, если мы говорим о западном мире), регулирование общественных взаимоотношений, связанных с миграцией и религией проистекает не из священных книг, а из требований или рекомендаций международных организаций, таких как, например, известные Love Makes a Way Australia, JRS France Welcome Project и т.д. Подобные организации широко представлены не только на международном, но и на локальном уровне. Так, Диалог Управления Верховного комиссара $\mathrm{OOH}$ по проблемам защиты беженцев (УВКБ ООН), который состоялся 
12-13 декабря 2012 года в Женеве, был посвящен теме «Вероисповедание и защита». Данное мероприятие собрало более 400 человек - представителей государств-членов $\mathrm{OOH}$, межправительственных организаций и неправительственных организаций, религиозных лидеров и ученых. По итогам мероприятия были разработаны планы по определению передовой практики в области миграции и религии, и повышению религиозной грамотности среди гуманитарных организаций. На основе данных планов коалиция религиозных лидеров различных конфессий разработала и опубликовала руководство по их реализации на период с февраля по апрель 2013 г. ${ }^{1}$ В 2014 г. было опубликовано Сообщение о партнерстве с религиозными организациями, местными религиозными общинами и религиозными лидерами - документ, предназначенный для сотрудников УВКБ ООН с рекомендациями о том, как установить контакт и взаимодействовать с разнородной группой религиозных деятелей.

Конечно, крайне важным последующим шагом, который не только будет способствовать выработке стратегий в области управления миграцией с учетом религиозных особенностей в мире, но и устранит дисбаланс между интересами Севера и Юга в части политики в отношении миграции и перемещений, являются прямые консультации с мигрантами, беженцами и перемещенными лицами о том, как они понимают свое положение. Такие мероприятия должны включать изучение взглядов мигрантов на то, с какими основными трудностями и проблемами они сталкиваются, и каким образом они хотят, чтобы им помогли, в том числе хотят ли они, чтобы религиозные деятели и религиозный подход были частью этого процесса.

В основу исследования лег междисциплинарный подход, а методы были подобраны в единстве общенаучной и частнонаучной методологии (в частности, абстра- гирование, обобщение, анализ, синтез, индукция, гипотетико-дедуктивный, диалектический и системный методы). Теоретическую основу работы составили актуальные международные публикации научного и прикладного характера, освещающие тему взаимосвязи миграции и религии. Эмпирическую базу исследования образуют результаты социологического опроса, проведенного автором среди резидентов всех 5 государственных центров постоянного пребывания мигрантов и беженцев в Республике Сербия «Возможность интеграции в принимающее сообщество с точки зрения самих мигрантов» (2019 г., опрошено 173 респондентов, статистическая мощность исследования 0,87 ) и результаты вторичного анализа данных социологических исследований: «Мнения граждан, проживающих в центральной части Республики Сербии, о влиянии мигрантов на традиции и культуру их местного сообщества» (2013 г., опрошено 1325 респондентов, руководители Мирьяна Бобич и Милица Вескович-Анжелкович), «Отношение граждан Сербии в просителям убежища» (2014 г., опрошено 600 респондентов, Центр свободных выборов и демократии) и «Исследования беженцев - Cербия 2016» Центра прикладных общественных исследований (2016 г., опрошено 986 респондентов, руководители Владимир Вулетич, Драган Станоевич, Елисавета Вукелич, Елена Пешич). Помимо этого, в работе представлены результаты авторского исследования способов представления миграционных процессов в новостных лентах СМИ (с 7.10.2017 г. по 10.10.2018 г., 119 медиа-сообщений в репрезентативных сербских электронных СМИ: 021, В92, N1, Danas, RTV Vojvodina, Informer, Blic, Kurir, Vesti online, Naslovi, Telegraf). Также были использованы результаты контент-анализа референтных справочно-аналитических и информационных материалов, освещающих вопросы миграции и религии. Интерпретация резуль-

\footnotetext{
${ }^{1} \mathrm{http}: / /$ www.patriarchia.ru/db/text/2651165.html.
} 
татов проводилась посредством статистических методов, дескриптивного и логического анализа.

Научные результаты и дискуссия (Research Results and Discussion). Прежде всего, отметим, что на основе располагаемых данных мы можем говорить о том, что в настоящее время большая часть мигрантов и беженцев являются мусульманами (World Migration Report, 2020). В частности, наше собственное исследование помогло выяснить, что 67,1 \% мигрантов и беженцев, оказавшихся в Республике Сербия в связи с Ев- ропейским миграционным кризисом, исповедуют ислам, 24,6 \% относят себя к христианам и $1,2 \%$ относят себя к индуистам, а $7,1 \%$ опрошенных позиционируют себя как атеисты (см. рис. 1). Вместе с тем, граждане Республики Сербия не воспринимают мигрантов как мусульман (UNHCR, 2014). C этим коррелирует и то, что в большинстве новостных сообщений о мигрантах прямо не говорится об исламе $(92,17 \%)$, в то время как небольшое количество медиасообщений упоминает некую связь миграций и ислама $(7,83 \%)$ (Вукчевич, 2019b).

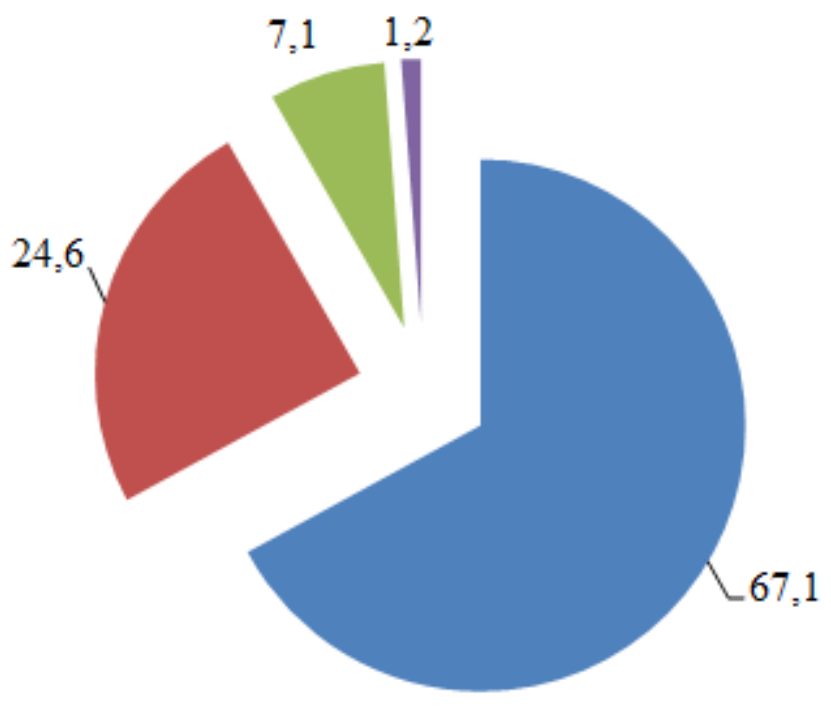

- Ислам

- Христианство

- Атеизм

- Индуизм

Рис. 1. Распределение выборки по вероисповеданию, \%

Fig. 1. Sample distribution by religion, $\%$

В рамках авторского социологического исследования мнения мигрантов и беженцев в Республике Сербия нами была рассмотрена взаимосвязь интеракции, политико-правовых, общественно-экономических и социокультурных переменных интеграции и различных характеристик целевой группы, в частности религиозной принадлежности респондентов. Проверка статистической взаимосвязи религиозной принадлежности и данных переменных, рассчитываемая при помощи непараметрического критерия Хи-квадрата, в большей части случаев показала отсутствие статистической значимости зависимости $(\mathrm{P}-$ значение $>0,05)$, что, тем не менее, не отрицает возможности наличия такой взаимосвязи (Вукчевич, 2019а). Исключением стала ситуация с вовлечением несовершеннолетних детей мигрантов в образовательный процесс в Республике Сербия. Поясним, что в рамках нашего опроса, на соответствующий вопрос анкеты отвечали только те респонденты, которые имеют несовершеннолетних детей школьного возраста, при этом мы исключили из рассмотрения ответы тех мигрантов, чьи несовершеннолетние дети школьного возраста не находились вместе с ними в Республике Сербия. В этом случае имеет место статистически значимая 
зависимость среднего значения между ответами респондентов разного вероисповедания $\left(\mathrm{X}^{2}(6)=14,713, \mathrm{P}=0,023, \mathrm{~V}=0,329\right)$. Таким образом, мы видим, что мусульмане чаще не отдают своих детей в школу в Республике Сербия (см. рис. 2).

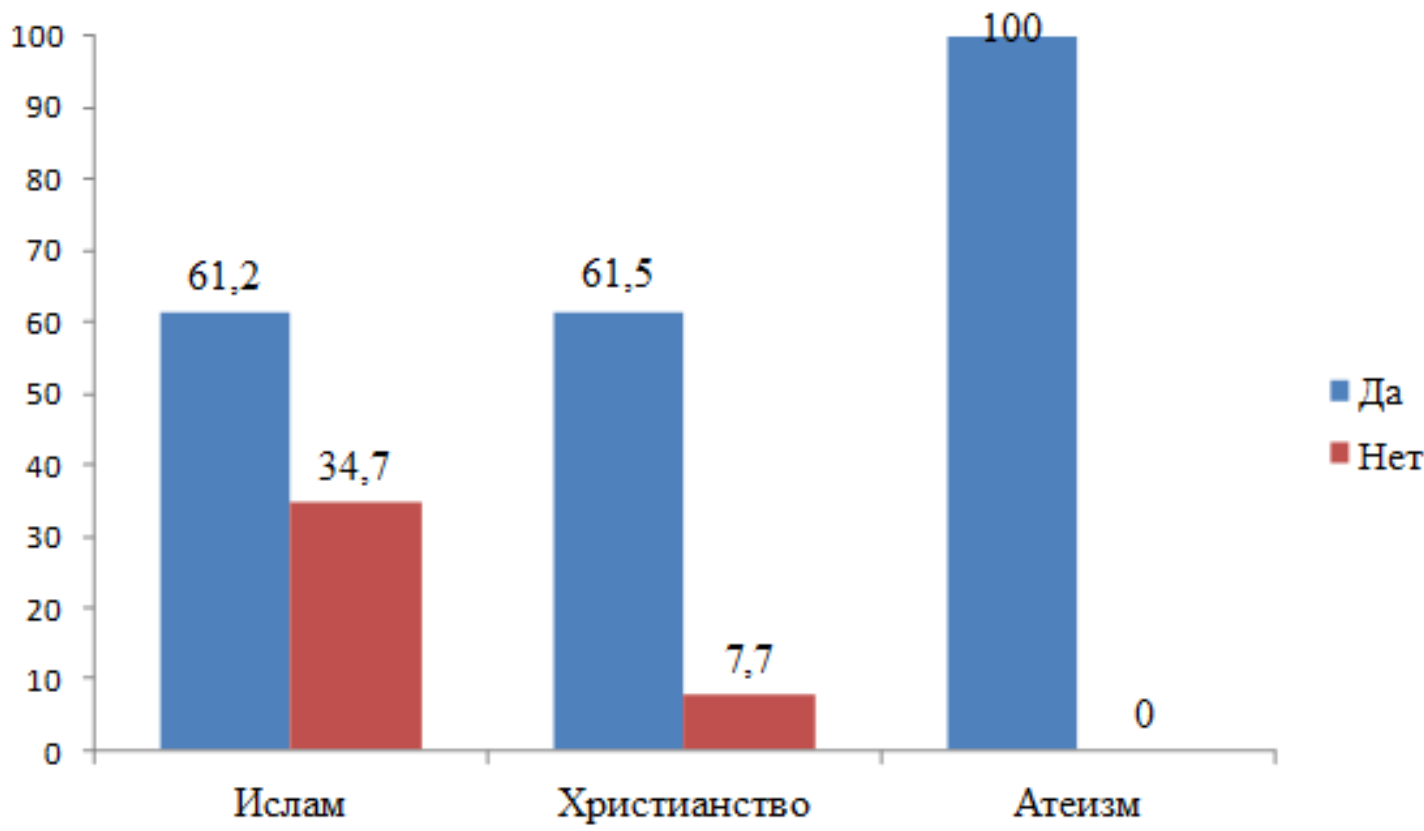

Рис. 2. Распределение ответов респондентов на вопрос о вовлечении несовершеннолетних детей в образовательный процесс в Республике Сербия, \%

Fig. 2. Distribution of respodents' answers to the question about the involvement of minors in the educational process in the Republic of Serbia, \%

По результатам изначального теста Хи-квадрат $\left(\mathrm{X}^{2}(5)=7,074\right.$ при уровне статистической значимости $\mathrm{P}-$ значение $=$ $0,215)$ можно сделать вывод, что нет существенной разницы в уровне урегулирования правового статуса в Республике Сербия для респондентов с различной религиозной принадлежностью (Вукчевич, 2019а). Ситуация аналогична в случае с участием в важных решениях $\left(\mathrm{X}^{2}(20)=19,142, \mathrm{P}=0,513\right)$, возможностью найти работу $\left(\mathrm{X}^{2}(10)=\right.$ $13,012, \mathrm{P}=0,223)$, доступом и удовлетворенностью медицинскими услугами $\left(\mathrm{X}^{2}(15)\right.$
$=15,935, \mathrm{P}=0,386)$, удовлетворенностью местом пребывания $\left(\mathrm{X}^{2}(20)=19,594\right.$, $\mathrm{P}=0,484)$, оценкой обеспечения основных прав, таких как работа, образование, здравоохранение и т.д. $\left(\mathrm{X}^{2}(10)=9,206, \mathrm{P}=\right.$ $0,513)$, возможностью изучать сербский язык $\left(\mathrm{X}^{2}(5)=8,503, \mathrm{P}=0.131\right)$, поддержка по вопросу интеграции $\left(\mathrm{X}^{2}(20)=17,953, \mathrm{P}=\right.$ $0,591)$ и возможностью практиковать этнические и культурные обычаи $\left(\mathrm{X}^{2}(10)=\right.$ 4,613, P = 0,916) (Вукчевич, 2019а). 
Таблица 1

Распределение ответов респондентов различного вероисповедания на вопрос о возможности свободно осуществлять религиозные практики

Table 1

Distribution of respondents' answers to the question about the possibility to freely practice their religion

\begin{tabular}{|c|c|c|c|c|c|}
\hline \multirow[b]{2}{*}{$\begin{array}{l}\text { Религиозная при- } \\
\text { надлежность/ } \\
\text { Religious affiliation }\end{array}$} & & \multicolumn{3}{|c|}{$\begin{array}{c}\text { Считаете ли Вы, что в Республике Сербия Вы можете } \\
\text { свободно осуществлять Ваши религиозные прак- } \\
\text { тики?/ Do you think that in the Republic of Serbia you } \\
\text { can freely exercise your religious practices? }\end{array}$} & \multirow[b]{2}{*}{$\begin{array}{l}\text { Всего/ } \\
\text { Total }\end{array}$} \\
\hline & & $\begin{array}{l}\text { Да, полно- } \\
\text { стью/ Yes, } \\
\text { completely }\end{array}$ & $\begin{array}{c}\text { Отдельные религиоз- } \\
\text { ные практики я могу } \\
\text { осуществлять, } \\
\text { а отдельные - нет/ I } \\
\text { can practice certain } \\
\text { religious practices, } \\
\text { and some - no }\end{array}$ & $\begin{array}{l}\text { Нет, не } \\
\text { могу/ No I } \\
\text { can not }\end{array}$ & \\
\hline \multirow{2}{*}{$\begin{array}{c}\text { Мусульмане/ } \\
\text { Muslims }\end{array}$} & $\mathrm{F}$ & 102 & 4 & 3 & 109 \\
\hline & $\%$ & 93,6 & 3,7 & 2,8 & 100,0 \\
\hline \multirow{2}{*}{$\begin{array}{c}\text { Христиане/ } \\
\text { Christians }\end{array}$} & $\mathrm{F}$ & 34 & 2 & 3 & 39 \\
\hline & $\%$ & 87,2 & 5,1 & 7,7 & 100,0 \\
\hline \multirow[t]{2}{*}{ Индуисты/ Hindus } & $\mathrm{F}$ & 2 & 0 & 0 & 2 \\
\hline & $\%$ & 100,0 & 0,0 & 0,0 & 100,0 \\
\hline \multirow{2}{*}{$\begin{array}{c}\text { Протестанты/ } \\
\text { Protestants }\end{array}$} & $\mathrm{F}$ & 1 & 0 & 2 & 3 \\
\hline & $\%$ & 33.3 & 0,0 & 66,7 & 100,0 \\
\hline \multirow[t]{2}{*}{ Шииты/ Shiites } & $\mathrm{F}$ & 2 & 0 & 0 & 2 \\
\hline & $\%$ & 100,0 & 0,0 & 0,0 & 100,0 \\
\hline \multirow[t]{2}{*}{ Атеисты/ Atheists } & $\mathrm{F}$ & 11 & 1 & 0 & 12 \\
\hline & $\%$ & 91,7 & 8,3 & 0,0 & 100,0 \\
\hline \multirow[t]{2}{*}{ Всего/Total } & $\mathrm{F}$ & 152 & 7 & 8 & 167 \\
\hline & $\%$ & 91,0 & 4,2 & 4,8 & 100,0 \\
\hline
\end{tabular}

В части возможности осуществлять религиозные практики, также не было выявлено статистически значимой взаимосвязи между религиозной принадлежностью респондентов и их ответами, абсолютное и относительное распределение которых представлено в таблице 1. Ответим, что часть респондентов-мусульман посчитало важным идентифицировать себя как шииты, а часть респондентов-христиан - как протестанты.

Говоря об интеракций мигрантов и беженцев с обществом-реципиентом, отметим, что, в целом мигранты, вне зависимости от вероисповедания $\left(\mathrm{X}^{2}(20)=15,722, \mathrm{P}\right.$ $=0,734)$, позитивно оценивают перспективу интеграции в местное сообщество в Республике Сербия $(73,4 \%$ ): незначительное количество негативных ответов наблюдается у мусульман и христиан, которые дают высокую оценку вероятности полной или частичной интеграции, атеисты демонстрируют наибольшим оптимизм по этому вопросу, тогда как протестанты опять более умеренны в своей оценке (Вукчевич, 2019a).

В тоже время, говоря об отношении местного принимающего сообщества к вопросу интеграции, отметим, что $37 \%$ согласны с тем, что национальные, религиозные и даже отличие в цвете кожи между 
сербскими гражданами и мигрантами и беженцами, которые находятся в стране слишком велики для того, чтобы они могли интегрироваться в местное сообщество (25\% не определились с ответом, $31 \%$ не согласны с этим) (UNHCR, 2014).

Это соотносится с тем, что большинство новостей о мигрантах несет негативное медиа-сообщение $(62,61 \%)$, а то время как лишь 26,09\% материалов имеет положительный характер, а 11,30 \% имеет нейтральную окраску. Однако, в большинстве своем негативный характер новостных сообщений о миграционных процессах не является последствием религиозной принадлежности мигрантов ни в том случае, когда речь идет о миграционных процессах в Сербии, ни в том случае, когда речь идет о миграционных процессах в мире (Вукчевич, 2019b).

В части оценки сосуществования с местным населением с точки зрения мигрантов, среднее распределение ответов у представителей всех вероисповеданий примерно одинаково $\left(\mathrm{X}^{2}(20)=6,182, \mathrm{P}=0,999\right)$. Индуисты лучше всего оценивают уровень взаимоотношений с сербским сообществом, а самую худшую оценку дают атеисты и протестанты. Интересно, что мусульмане не отмечают низкий уровень взаимоотношений с местным населением, которое в большинстве регионов Республики Сербия является христианским (православным) (Вукчевич, 2019а).

Весьма позитивным и обнадеживающим фактором является то, что, за исключением редких случаев (20 человек из 173), у мигрантов не было проблем с местным населением, что позволяет говорить о его толерантности и веротерпимости в официально секулярной Республике Сербия. Статистически значимой зависимости распределения ответов респондентов и их вероисповедания не выявлено $\left(\mathrm{X}^{2}(5)=1,507, \mathrm{P}=\right.$ $0,912)$. То же самое касается аспекта взаимоотношений с органами власти в Республики Сербия (всего 12 человек из 173 отметило случаи возникновения здесь проблем), без статистически значимой зависимости от религиозной принадлежности респондентов $\left(\mathrm{X}^{2}(5)=5,754, \mathrm{P}=0,331\right)$ (Вукчевич, 2019a).

В то же время, В. Вулетич, Д. Станоевич, Е. Вукелич и Е. Пешич отмечают, что у ряда представителей власти и местного самоуправления в Республике Сербия прослеживается узнаваемое и четкое отношение к вопросам религии в контексте миграции. Так, в этнически смешанных районах на юго-востоке Сербии интеракции различных религиозных и этнических групп более интенсивные. Поэтому, если это возможно, тут следует принимать во внимание конфессиональную идентификацию и религиозные обычаи мигрантов и беженцев. Эксперты считают, что вновь прибывшее население будет легче интегрироваться и, что отторжение будет меньше в случае, когда мигранты и беженцы имеют ту же религиозную принадлежность, что и местное население. Например, в таких регионах зачастую инфраструктура уже позволяет беспрепятственно совершать религиозные обряды. С другой стороны, в таких регионах миграционные процессы потенциально могут вызвать страх разрушения существующих взаимоотношений между конфессиями и последователями различных религий. На юге Сербии, в частности в граничащих с Косово и Метохией районах, где преимущественно проживает православное население, принимающее сообщество беспокоит вопрос религиозной принадлежности мигрантов. Представители локальных властей и местных администраций здесь говорят о том, что их муниципалитеты в случае необходимости готовы принимать мигрантов-мусульман, но в меньшем количестве (CPDI, 2016: 46).

Готовность местного населения терпимо относиться к культурному, этническому и религиозному многообразию и взаимопроникновению, обусловленному влиянием мигрантов и беженцев, является еще одним важным аспектом интеграции. Степень толерантности в значительной степени определяет модель интеграции, кото- 
рая применяется в рамках механизма управления миграционными процессами в стране. Для оценки уровня толерантности общества-реципиента в Республики Сербия по отношению к мигрантам и беженцам специалисты Центра прикладных общественных исследований обратились к уже упомянутому выше «парадоксу хиджаба». Полученные ими данные, относящийся к вызывающему многочисленные споры в европейских странах вопросу о закрытии мусульманскими женщинами лиц, показывают, что чуть более трети респондентов считают это их правом и не возражают против данного типа проявления культурной специфики мигрирующего населения. Готовность проявить толерантность по отношению к традиционным нормам одежды только временно проживающих в Сербии мусульманских женщин выражают еще $11,4 \%$ респондентов. С другой стороны, $18,9 \%$ респондентов считают, что головной убор недопустим, если женщины-мигранты планируют остаться в Сербии, в то время как почти для пятой части респондентов хиджаб полностью не приемлем (CPDI, 2016: 20-21). Интерпретируя эти результаты, следует иметь в виду, что относительно высокая доля респондентов, не приемлющих закрытие лица мусульманскими женщинами, не обязательно являются результатом нетерпимости к культурному разнообразию. Это может быть объяснено общим отхождением от традиционных норм одежды и поведения, которые также присутствуют среди местного мусульманского населения в Республике Сербия.

Другой аспект толерантности к культурному, этническому и религиозному разнообразию, который исследовали специалисты Центра прикладных общественных исследований, связан с готовностью граждан проявлять терпимость к строительству новых мечетей в Сербии, чтобы позволить мусульманским мигрантам осуществлять религиозные обряды. Чуть больше половины респондентов (50,8 \%) не видят проблемы в строительстве мечетей для мигрантов, исповедующих ислам, против выступает более трети респондентов. Совершенно неожиданным результатом, так же, как и для нас в рамках проведенного нами опроса мигрантов, стало отсутствие статистически значимых различий в ответах респондентов различной религиозной принадлежности. Иными словами, мусульманское вероисповедание не дает больших шансов для более терпимого отношения к исламу по сравнению с другими религиями. Интерпретируя эти данные, по мнению В. Вулетича, Д. Станоевича, Е. Вукелич и Е. Пешич, необходимо помните о следующих вещах. Во-первых, мусульманское население в Сербии принадлежит к группам меньшинств, поэтому его представители часто пытаются дать социально приемлемые ответы и, следовательно, существенно не отклоняются от взглядов большинства населения. Также следует иметь в виду, что даже внутри одних и тех же религиозных или этнических групп существует «конкуренция культур», которая возникает вокруг права на исключительное религиозное толкование и связанные с ним привилегии. Наконец, нетрудно предположить, что для части местного мусульманского населения возвращение к традиционным нормам также может стать нежелательным (CPDI, 2016: 20-21).

По мнению самих мигрантов и беженцев, которые участвовали в нашем опросе, местное население в Республике Сербия демонстрирует достаточно высокий уровень толерантности по отношению к культурным, этническим и религиозным различиям (см. табл. 2). При этом наши расчёты показали отсутствие статистически значимой зависимости в распределении ответов респондентов с различной религиозной принадлежностью (Вукчевич, 2019а).

Таблица 2

Распределение ответов респондентов различного вероисповедания на вопрос о толерантности принимающего общества

Table 2 
Distribution of respodents' answers to the question about tolerance in the host society

\begin{tabular}{|c|c|c|c|c|c|c|c|}
\hline \multirow{2}{*}{\multicolumn{2}{|c|}{$\begin{array}{c}\text { Религиозная принадлеж- } \\
\text { ность/ Religious } \\
\text { affiliation }\end{array}$}} & \multicolumn{5}{|c|}{$\begin{array}{l}\text { В какой мере, по Вашему мнению, и в соответствии с } \\
\text { Вашим опытом, в Республике Сербия проявляется то- } \\
\text { лерантность по отношению к культурным, этниче- } \\
\text { ским и религиозным различиям?/ Tо what extent, in } \\
\text { your opinion, and in accordance with your experience, is } \\
\text { tolerance towards cultural, ethnic and religious differ- } \\
\text { ences manifested in the Republic of Serbia? }\end{array}$} & \multirow[b]{2}{*}{$\begin{array}{c}\text { Всего/ } \\
\text { Total }\end{array}$} \\
\hline & & 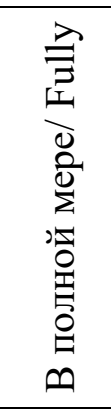 & 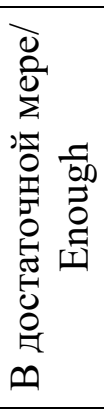 & 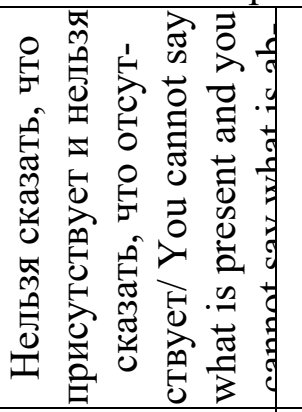 & 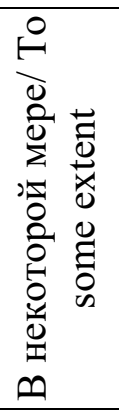 & 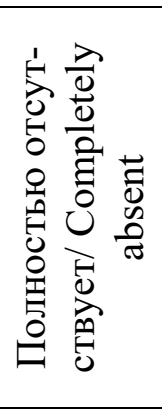 & \\
\hline \multirow{2}{*}{$\begin{array}{c}\text { Мусульмане/ } \\
\text { Muslims }\end{array}$} & $\mathrm{F}$ & 62 & 31 & 13 & 4 & 0 & 110 \\
\hline & $\%$ & 56,4 & 28,2 & 11,8 & 3,6 & 0,0 & 100,0 \\
\hline \multirow{2}{*}{$\begin{array}{c}\text { Христиане/ } \\
\text { Christians }\end{array}$} & $\mathrm{F}$ & 25 & 7 & 4 & 1 & 2 & 39 \\
\hline & $\%$ & 64,1 & 17,9 & 10,3 & 2,6 & 5,1 & 100,0 \\
\hline \multirow[t]{2}{*}{ Индуисты/ Hindus } & $\mathrm{F}$ & 2 & 0 & 0 & 0 & 0 & 2 \\
\hline & $\%$ & 100,0 & 0,0 & 0,0 & 0,0 & 0,0 & 100,0 \\
\hline \multirow{2}{*}{$\begin{array}{c}\text { Протестанты/ } \\
\text { Protestants }\end{array}$} & $\mathrm{F}$ & 1 & 0 & 0 & 2 & 0 & 3 \\
\hline & $\%$ & 33,3 & 0,0 & 0,0 & 66,7 & 0,0 & 100,0 \\
\hline \multirow[t]{2}{*}{ Шииты/ Shiites } & $\mathrm{F}$ & 1 & 1 & 0 & 0 & 0 & 2 \\
\hline & $\%$ & 50,0 & 50,0 & 0,0 & 0,0 & 0,0 & 100,0 \\
\hline \multirow[t]{2}{*}{ Атеисты/ Atheists } & $\mathrm{F}$ & 6 & 2 & 4 & 0 & 0 & 12 \\
\hline & $\%$ & 50,0 & 16,7 & 33,3 & 0,0 & 0,0 & 100,0 \\
\hline \multirow[t]{2}{*}{ Всего/Total } & $\mathrm{F}$ & 97 & 41 & 21 & 7 & 2 & 168 \\
\hline & $\%$ & 57,7 & 24,4 & 12,5 & 4,2 & 1,2 & 100,0 \\
\hline
\end{tabular}

В целом, мы можем говорить о положительной ситуации по вопросу принятия мигрантов у местного населения по оценкам самих мигрантов. При том, что нами не было выявлено статистически значимой зависимости вероисповедания и ответов респондентов $\left(\mathrm{X}^{2}(20)=14,659, \mathrm{P}=0,796\right)$, отметим следующие особенности. Индуисты и шииты едины во мнении, что в сербском обществе нет неприятия мигрантов. Интересно, что более $20 \%$ остальных мусульман, как и христиан, отмечают, что «нельзя сказать, что отторжение есть, но также нельзя сказать, что его нет», а около $40 \%$ респондентов, исповедующих указанные религии, говорят, что неприятия нет. Протестанты и атеисты уверены в этом чуть в меньшем количестве. Также отметим, что атеисты также не дают полностью негативный ответ на этот вопрос. Однако, именно у протестантов наблюдается самая многочисленная статистика выбора ответа о повсеместном присутствии отторжения (Вукчевич, 2019а).

В то же время в обществе-реципиенте имеют место большие различия в готовности принять мигрантов и беженцев в зависимости от религиозной принадлежности респондентов. Самое сильное неприятие любого вида постоянного пребывания мигрантов и беженцев на территории Сербия было 
отмечено среди респондентов православного вероисповедания (47,1 \%), а наименьшая отторжение наблюдается среди атеистов $(16,7 \%)$ и мусульман $(25 \%)$. В то же время среди данных двух категорий респондентов зафиксировано больше всего сторонников постоянного пребывания мигрантов в Сербии. Хотя ни один из респондентов, исповедующих ислам, не готов смириться с тем, что мигранты и беженцы на постоянной основе селятся на территории их муниципального образования. Интересно отметить, что среди респондентов, назвавших себя атеистами, наибольшая доля тех, кто полностью равнодушен к нахождению мигрантов и беженцев стране (CPDI, 2016: 16).

Массовое переселение людей совершенно другого социокультурного происхождения в качестве последствия влечет за собой более или менее крупные изменения в существующих этнических и религиозных структурах общества. Действительно, «международные потоки мигрантов способствуют перераспределению «мировых религий» по регионам земного шара» (Beckfor, 2019: 16). В рамках опроса Центра прикладных общественных исследований большинство респондентов (52,1\%) высказало мнение о том, что интеграция беженцев и перемещенных лиц, а также экономических мигрантов из Азии и Африки будет иметь большее или меньшее значение для общества в этническом и религиозном плане. Значительно меньше тех, кто не видит тут предпосылок для существенных изменений (26,1 \%), а 14,6 \% - высказались нейтрально. В части данного вопроса, как и ряда предыдущих, относительно большое количество респондентов не знало, как ответить (12\%) (CPDI, 2016: 41-42).

Для сравнения, в этой связи целесообразно привести данные опроса, связанного с отношением к населению, прибывшему из государств бывшей Югославии, и к приезжим из Китая (двум группам переселенцев, сформированным по принципу культурной близости). В ходе анализа полученных результатов, исследователи пришли к выводу, что представители местного сообщества в большей степени обращают внимание на экономическое, чем на культурное влияние мигрантов в широком смысле. Другими словами, степень определенности респондентов в отношении мнения о влиянии мигрантов на экономику больше, нежели степень их определенности в отношении к влиянию мигрантов на местную культуру. Такое положение вещей может быть обусловлено отсутствием интереса у местного сообщества к переменам, которые не представляют угрозу материальному благополучию. Высокая степень неопределенности в части отношения к культурному влиянию мигрантов на местное сообщество и малая разница во мнениях по этому вопросу у местного и приезжего населения в целом указывает на относительное принятие иммигрантов. Это не подразумевает их культурную ассимиляцию и не умаляет их собственную идентичность, а указывает на уровень толерантности и открытости местного населения в Республике Сербия (Bobić \& Vesković Anđelković, 2015).

«Миграция может предоставить возможности для развития новых или гибридных религиозных убеждений, идентичностей, практик и способов интеграции в общество» (Beckfor, 2019: 17). Помимо изменения религиозно-этнического состава, перемещение людей, которые по своим социокультурным особенностям значительно отличное от постоянного населения, может способствовать повышению толерантности и культурной интеграции. Правильное направление практической миграционной политики страны в неблагоприятных условиях миграционного кризиса может задать развитие многокультурного общества для установления равновесия социальной системы (Parsons, 1951). Однако, по данным Центра прикладных общественных исследований, преобладающие позиции респондентов не согласуется с этим утверждением. Так, менее трети респондентов считают, что прибытие и более постоянное пребывание мигрантов способствует развитию толерантной и многокультурной среды, в то время как четверть отвергает такую перспективу. 
Около четверти респонденты (23 \%) затруднились с ответом на этот вопрос. По мнению трети респондентов, мигранты не окажут положительного или отрицательного воздействия на культурную среду в Сербии. Почти пятая часть респондентов видит более-менее благоприятные эффекты, а более трети опрошенных граждан выделяют негативных моментов. Судя по распределению ответов респондентов на вопрос об отношения к культурным аспектам интеграции мигрантов, среди для тех, кто назвал себя православными христианами, положительный эффект видят $18,8 \%$ опрошенных, нейтральные последствия отмечают $28,4 \%$, относительно большая часть (38,3\%) полагает, что воздействие будет более или менее неблагоприятным. Среди тех, кто назвал себя католиками намного меньше доля тех, кто видит эффекты в неблагоприятном свете $(18,9 \%)$, в то время как больше количество тех, кто ожидает, что взаимопроникновение не будет иметь ни благоприятных, ни неблагоприятных последствий $(39,2 \%)$, позитивные ожидания имеют немного меньшая доля $(12,2 \%)$, чем у респондентов с православной религиозной принадлежностью. Среди опрошенных атеистов большинство составляют те, кто не ожидает ни положительных, ни отрицательных эффектов $(41,7 \%)$, за ними следуют те, у кого есть положительные ожидания $(33,4 \%)$, хотя это убедительно меньше всего ожидающих неблагоприятных последствий (13,9 \%) (CPDI, 2016: 41-42).

Заключение (Conclusion). Несмотря на то, что миграция и религия не часто рассматриваются в комплексе, подобный подход полностью оправдан, поскольку взаимосвязь двух феноменов находит отражение в различных сферах жизни общества. Темы миграции и религии переплетаются как в текстах священных книг, являющихся нематериальной основой религии, так и в официальных и международнопризнанных

${ }^{1}$ UNHCR (2014), Public opinion poll report:Attitudes of Serbian citizens towards asylum seekers, UNHCR/CESID, Belgrade, Serbia, [Online], available нормативно-правовых актах, а также в деятельности неправительственных и других организаций, чья гуманитарная деятельность строится на религиозных основах, и в жизни самих мигрантов. Взаимосвязь миграции и религии проявляется во многих социальных группах: в семьях, где разные покаления мигрантов отличаются уровнем своей религиозности; в малых социальных группах, за которые религиозные организации либо, «конкурируют», как за целевую аудиторию или клиентов, либо подвергают их социальной изоляции; в маргинализированных сообществах, как, например, в трюрьмах, где представитель религиозной ораганизации зачастую отождествляется с единственным доступным способом интеракции с окружающим миром. Подобная взаимосвязь достаточна сильна и имеет двустороннюю направленность, так как мигранты и сами могут воздействовать на религиозные сообщества и видоизменять их. В связи с этим имеет место значительная диллема в части такого чувствительного вопроса как, то способствуют ли мигранты реализации интересов религиозного объединения и его укреплению и действительно ли религия помогает мигрантам.

Результаты нашей работы показывают, что религия не обязательно является той призмой, сквозь которую воспринимаются мигранты. Так, несмотря на то, что в своем большинстве мигранты в Республике Сербия являются мусульманами, они не отождествляются местным населением с исламом ${ }^{1}$. Однако эта призма весьма изменчима под влиянием СМИ. Картина миграционных процессов в электронных медиа транслируется достаточно широко (в среднем, каждый третий день появляются новостные сообщения на тему миграции). Поэтому, мы можем говорить о том, что про-

at: http://www.unhcr.rs/media/CeSIDUNHCR201014FIN AL.pdf (Accessed 20.09.2020). 
блема миграции пласируется в фокус общественного внимания именно таким образом. Также, на основе проведенной исследовантельской работы и статистической обработки собранных данных мы можем сделать вывод о том, что лишь незначительная часть имеющих прямую связь с миграционными процессами медиасообщений проводит связь между миграцией и религией (Вукчевич, 2019b).

Наряду с этим, анализ данных социологических исследований показал, что хотя мигранты с различной религиозной принадлежностью значительно не отличаются в части своего подхода к интеграции с местным сообществом (Вукчевич, 2019а), в одном и том же государстве обществореципиент по разному реагирует на миграцию и на религию мигрантов в зависимости от своего географического расположения на Юге или на Севере (CPDI, 2016), что на первый взгляд может быть объяснено с помощью социологии истории и в связи со структурой населения, однако данное явление без сомнения требует дальнейших исследований. В ходе анализа полученных результатов, можно сделать вывод о том, что представители местного сообщества в большей степени обращают внимание на экономическое, чем на культурное влияние мигрантов в широком смысле (Bobić \& Vesković Anđelković, 2015).

Если говорить о взаимосвязи миграции и религии в контексте культурной интеграции в общество-реципиент на примере Республики Сербия, то полученные в этой связи данные непременно следует интерпретировать на основе того, что значительная часть мигрантов является мусульманами, и что степень культурной дистанции по отношению к ним меньше среди постоянного мусульманского населения, чем у респондентов православного и римско-католического вероисповедания. С другой стороны, низкая готовность мусульман смириться с постоянным пребыванием мигрантов на территории своего муниципального образования свидетельствует о том, что политический аспект интеграции мигрантов (помимо экономического и культурного) также необходимо иметь в виду. В частности, в определенных, в первую очередь приграничных местных сообществах, религиозная принадлежность сильно связанна с этнической принадлежностью и любое нарушение хрупкого религиозного и этнического баланса может восприниматься как потенциальный источник политической нестабильности, радикализации существующих межнациональных конфликтов и усиления давления центральной власти на органы местного самоуправления (даже, если локально имевшая место стабильность была в пользу меньшинства). Постоянное нахождение мигрантов и беженцев дополнительно увеличивает давление на и без того слабое предложение рабочих мест в неразвитых муниципалитетах на Юге, и можно сделать вывод, что отторжение мигрантов местным населением, помимо политической, имеет рациональную, экономическую основу (CPDI, 2016: 16).

С точки зрения классической социологии, религия является не только лишь отражением общественных явлений или симптомом перемен, но также их источником. В условиях глобализации социологическая наука должна ставить перед собой вопрос о том, в действительности ли религия все еще играет основополагающую роль в интеграции общества и социальном развитии (Knoblauch, 2004: 278). Миграция лишь усложняет данную проблему, что дополнительно актуализирует необходимость изучения ее взаимосвязи с религией. Также, необходимо принимать во внимание, что «мигранты и сообщества мигрантов взаимодействуют как на местном, так и на транснациональном уровнях, причем часто одновременно» (Frederiks, 2016: 15). Это усложняет изучение вопроса взаимосвязи миграции и религии и почти полностью исключает возможность универсального решения. Действительно, решение приемлемое для одного уровня взаимодействия и для одного географического пространства может быть деконструктивным в иных условиях. 


\section{Список литературы}

Ager A., Ager J. Religion, Forced Migration, and Humanitarian Response // Intersections of Religion and Migration. Religion and Global Migrations; Saunders J., Fiddian-Qasmiyeh E., Snyder S. (eds.). New York: Palgrave Macmillan, 2016. P. 285-310.

Beckford J. A. Religions and migrations old and new // Quaderni di Sociologia. Beyond the Refugee Crisis: Migrations and Religions in Europe. 2019. № 63 (80). P. 15-32.

Bobić M., Vesković Anđelković M. Stavovi građana centralnog dela Srbije prema uticaju doseljenika na tradiciju i kulturu njihove lokalne zajednice // Migracije i etnićke teme. 2015. godina 31, kolovoz 2015, broj 2. Str. 221-246.

Cesari J. Religion and Diasporas: Challenges of the Emigration Countries [Text] // Migrant Integration Between Homeland and Host Society / Weinar A., Unterreiner A., Fargues P. (eds.). Vol. 1. Cham: Springer. 2017. P. 173-199.

CPDI. Studija o izbeglicama - Srbija 2016 / Centar za primenjena društvena istraživanja. Beograd: Fondacija Fridrih Ebert. 2016. [Online], available at: http://library.fes.de/pdffiles/bueros/belgrad/12928.pdf

(Accessed 20.09.2020).

Frederiks M. Th. Religion, Migration and Identity: A Conceptual and Theoretical Exploration // Theology and Mission in World Christianity / Frederiks M., Nagy D. (eds.). Vol. 2. MA: ESSAY. Henry J. Leir Institute. The Fletcher School of Law and Diplomacy. Tufts University. 2016. P. 9-29.

Huntington S. P. The Clash of Civilizations and the Remaking of World Order. NY: Simon and Schuster. 1996. 367 p.

Knoblauch, H. Sociologija religije / Markešić I. (prev.) Zagreb: Emetra. Vol. 14. 2004. $318 \mathrm{p}$.

Parsons T. The Social System. Glencoe, IL: Free Press. 1951. 575 p.

Saunders J. B., Fiddian-Qasmiyeh E., Snyder S. Introduction: Articulating Intersections at the Global Crossroads of Religion and Migration // Intersections of Religion and Migration. Religion and Global Migrations / Saunders J., FiddianQasmiyeh E., Snyder S. (eds). NY: Palgrave Macmillan. 2016. P. 1-46.

World Migration Report 2020 / McAuliffe M., Khadria B. (eds.). Geneva: IOM. 496 p.
[Online], available at: https://www.iom.int/wmr/ (Accessed 20.09.2020).

Бедин Д. А., Гридчин А. А. Межрелигиозные отношения, как источник социальной напряженности // Современная социология: состояние и перспективы. Материалы международного семинара-дискуссии. Белгород: Издво: Белгородский технологический институт строительных материалов, 1992. С. 76-78.

Вукчевич Н. Дескриптивный анализ фактора религии в отношении мигрантов к новому окружению // Научный результат. Социология управления. 2019а. Т. 5, № 4. C. 84-90.

Вукчевич Н. Медиа-картины процессов миграции на интернет-порталах в Сербии 20172018 гг. // Миграция как ресурс социально-экономического и демографического развития: сборник статей. Серия «Демография. Социология. Экономика». Том 5, № 3; Под редакцией чл.-корр. РАН С. В. Рязанцева, к.ф.-м.Н. М. Н. Храмовой, к.э.н. А. С. Максимовой. М.: изд-во Экон-Информ, 2019b. С. 127-134.

Вукчевич Н. Традиционная религиозность и миграционный процесс // Different forms of religiosity and the modern world (thematic conference proceedings of international significance held in Srebrno jezero (Veliko Gradište, Serbia, 26-27 April 2018) / editors Mirko Blagojević, Zlatko Matić. Belgrade: Institute of Social Sciences; Požarevac: Department of Education and Culture, Serbian Orthodox Diocese of Braničevo; Belgrade: Faculty of Technology and Metallurgy, Research and development Centre of Printing Technology, 2019c. C. 182-201.

Гридчин А. А. Проблема миграции, беженцев и вынужденных переселенцев в деятельности международных организаций // Общество: экономика, политика, право. 2008. № 2. C. 2-5.

Священный Коран в переводе, с комментариями А.Ю. Али. Нижний Новгород: Издательский дом «Медина», 2007. 1741 с.

\section{References}

Ager, A. and Ager, J. (2016), "Religion, Forced Migration, and Humanitarian Response", in Saunders, J., Fiddian-Qasmiyeh, E. and Snyder, S. (eds.), Intersections of Religion and Migration. Religion and Global Migrations, Palgrave Macmillan, N.Y., USA, 285-310.

Beckford, J. A. (2019), "Religions and migrations - old and new", Quaderni di Sociologia, 
Beyond the Refugee Crisis: Migrations and Religions in Europe, 63 (80), 15-32.

Bobic, M. and Veskovic Anđelkovic, M. (2015), "Attitudes of the citizens of Central Serbia towards imigrants influence on the tradition and culture of their local community", Migracije i etničke teme, 31 (2), 221-246.

Cesari, J. (2017), "Religion and Diasporas: Challenges of the Emigration Countries", in Weinar, A., Unterreiner, A. and Fargues, P. (eds.), Migrant Integration Between Homeland and Host So-ciety, 1, Springer, Cham, Germany, 173-199.

CPDI (2016), Refugee Study-Serbia 2016, Centar za primenjena društvena istraživanja, Fondacija Fridrih Ebert, Beograd, Serbia, [Online], available at: http://library.fes.de/pdffiles/bueros/belgrad/12928.pdf (Accessed 20.09.2020).

Frederiks, M. Th. (2016), "Religion, Migration and Identity: A Conceptual and Theoretical Exploration", in Frederiks, M. and Nagy, D. (eds.), Theology and Mission in World Christianity, 2, ES-SAY, Henry J. Leir Institute, The Fletcher School of Law and Diplomacy, Tufts University, MA, USA, 9-29.

Huntington, S. P. (1996), The Clash of Civilizations and the Remaking of World Order, Simon and Schuster, N.Y., USA, 367.

Knoblauch, H. (2004) Sociologija religije [Sociology of Religion], translated by Markešić, I., Emetra, Zagreb, Croatia, 14, 318.

Parsons, T. (1951), The Social System, Free Press, Glencoe, IL, USA.

Saunders, J. B., Fiddian-Qasmiyeh, E. and Snyder, S. (2016), "Introduction: Articulating Intersections at the Global Crossroads of Religion and Migration", in Saunders, J., FiddianQasmiyeh, E. and Snyder, S. (eds.) Intersections of Religion and Migration. Religion and Global Mi-grations, Palgrave Macmillan, N.Y., USA, $1-46$.

World Migration Report 2020 (2020), McAuliffe, M. and Khadria, B. (eds.), IOM, Geneva, Switzerland, 496. [Online], available at: https://www.iom.int/wmr/ (Accessed 20.09.2020).
Bedin, D. A. and Gridchin, A. A. (1992), "Interfaith realtions as a source of social tension", Sovremennaia sotsiologiia sostoianie $i$ perspektivy, Proceedings of the international seminar-discus-sionn, Izd-vo Belgorodskii tekhnologicheskii insti-tut stroitelnykh materialov, Belgorod, Russia, 76-78. (In Russian)

Vukcevic, N. (2019a), “A descriptive analysis of the religion factor in relations of migrants to a new environment", Research result. Sociology and Management, 5 (4), 84-90. (In Russian)

Vukcevic, N. (2019b), "Media Image of migration process on Internet portals in Serbia 2017-2018“, in Riazantsev, S. V., Khramova, M. N. and Maksimova A. S. (eds.) Migratsiia kak resurs sotsialno-ekonomicheskogo i demograficheskogo razvitii. Demografiia. Sotsiologiia. Ekonomika. Collection of articles, 5 (3), Izd-vo Ekon-Inform, Moskva, Russia, 127-134. (In Russian)

Vukcevic, N. (2019c), "Traditional religiosity and migration processes", in Blagojević, M. and Matić, Z. (eds), Different forms of religiosity and the modern world, Thematic conference proceedings of international significance held in Srebrno jezero, Veliko Gradište, Serbia, April 26 and 27 of 2018, Institute of Social Sciences, Belgrade, Serbia; Department of Education and Culture, Serbian Orthodox Diocese of Braničevo, Požarevac, Serbia; Faculty of Technology and Metallurgy, Research and development Centre of Printing Technology, Belgrade, Serbia, 182-201. (In Russian)

Gridchin, A. A. (2008), "The problem of migration, refugees, and internally displaced persons in the international organizations activities, Obshchestvo: ekonomika, politika, pravo, (2), 2-5. (In Russian)

Quran (2007), translated by Ali, A. Yu., Izdatelskiy dom Medina, Nizhniy Novgorod, Russia. (In Russian)

Статья поступила в редакцию 01 июля 2020 г. Поступила после доработки 20 агуста 2020 г. Принята к печати 02 сентября 2020 г.

Received 01 July 2020. Revised 20 August 2020. Accepted 02 September 2020. 
Конфликты интересов: у автора нет конфликта интересов для декларации.

Conflicts of Interest: the author has no conflict of interest to declare.
Вукчевич Неманя, аспирант, Университет Белграда.

Nemanja Vukcevic, PhD Student, University of Belgrade. 